\title{
Penerapan Metoda Serial Peripheral Interface (SPI) pada Rancang Bangun Data Logger berbasis SD card
}

\author{
RATNA SUSANA, MUHAMMAD ICHWAN, SAVERO AL PHARD \\ Institut Teknologi Nasional Bandung \\ Email : ratnassn@yahoo.com
}

\begin{abstract}
ABSTRAK
Serial Peripheral Interface (SPI) adalah protokol komunikasi yang dapat digunakan sebagai interface komunikasi antara mikrokontroler dengan SD Card. Dengan menerapkan metoda SPI pada data logger berbasis SD Card, maka dapat diketahui karakteristik protokol komunikasi SPI antara mikrokontroler dengan SD Card. SD Card diformat dengan tipe FAT 16, dan data di dalam SD Card berupa sekumpulan paket data sensor yang diambil secara periodik dan disimpan dalam bentuk file dengan format.csv. Berdasarkan format paket data sensor yang dibuat, dapat dihitungwaktu perekaman data yang diperlukan agar kapasitas SD Card terisi penuh oleh data sensor. Hasil penelitian menunjukkan,bahwa metoda SPI yang diterapkan pada penelitian ini memiliki sifat akan melakukan pemeriksaan berulang pada pin MISO terhadap command yang dikirimkan oleh mikrokontroler melalui pin MOSI. Proses read/write data pada SD Card data logger memiliki keberhasilan 100\%, karena SD Card telah terinisialisasi dalam mode SPI melalui perintah reset dan init SD Card. Komunikasi ini dapat dilakukan dengan menggunakan crystal 4 Mhz - 20 Mhz. Untuk pengujian konfigurasi SPI, hanya Independent Slave Configuration yang dapat digunakan pada komunikasi SPI dengan 2 SD card sebagai slave.
\end{abstract}

Kata kunci : Serial Peripheral Interface (SPI), Data Logger, SD card, FAT16

\begin{abstract}
Serial Peripheral Interface (SPI) is a communication protocol that can be applied as a communication interface between microcontroller to SD Card. By implementing the SPI method to a data logger based on SD Card, it can be known the characteristics of the SPI communications protocol between microcontroller to SD Card. SD Card formatted in FAT 16 type, and data on the SD Card is the form of sensor data packets collection which be captured periodically and saved in .csv format file. Based on the sensor data packet format is created, it can be calculated recording time data required so that the SD Card capacity completely filled by the sensor data. Research results show, that the SPI method applied in this study has the properties will do repeated testing on MISO pin to the command sent by the microcontroller through the MOSI pin. The read / write data on the SD Card data logger has a 100\% success, because the SD Card has been initialized in SPI mode through the reset and init SD Card command. This communication can be established using crystal $4 \mathrm{Mhz}-20$ Mhz. At SPI configuration testing, only the Independent Slave Configuration can be used in SPI communication with 2 SD card as a slave.
\end{abstract}

Kata kunci : Serial Peripheral Interface (SPI), Data Logger, SD card, FAT16 


\section{PENDAHULUAN}

Data logger merupakan perangkat elektronik yang terhubung dengan sensor dan berfungsi untuk mencatat data secara berkala (Badhiye, dkk, 2011). Perangkat ini dapat diaplikasikan pada sistem-sistem yang memerlukan pencatatan ataupun perekaman data secara otomatis. Sesuai dengan fungsinya data logger dilengkapi dengan mikrokontroler dan memerlukan memori untuk menyimpan data. Memori yang digunakan dapat berupa memori internal di dalam mikrokontroler ataupun memori eksternal.

Beberapa data logger dirancang dan diimplementasikan menggunakan mikrokontroler yang terhubung dengan memori eksternal jenis SD card. SD card digunakan sebagai media penyimpanan data dari sejumlah parameter data hasil pengukuran(Vojtech, 2011; Nhivekar, 2011; Rudi, 2013; Dutta, 2014). Agar mikrokontroler dengan SD card dapat saling berkomunikasi, dalam hal ini adalah melakukan proses read/write data, maka diperlukan suatu protokol komunikasi yang dapat menghubungkan keduanya. SD card terhubung dengan mikrokontroler melalui protokol komunikasi Serial Peripheral Interface(SPI)(Vojtech, 2011; Nhivekar, 2011; Dutta, 2014). SPI merupakan protokol komunikasi dengan interfacing yang sederhana dan kecepatan yang dimilikinya masih memungkinkan untuk terjadinya komunikasi transfer data dengan mudah (Choudhury,2014).

Penggunaan memori eksternal pada data logger menjadi sangat dibutuhkan ketika sistem yang dibangun memerlukan pencatatan dan perekaman data dalam jumlah besar. Salah satu memori eksternal yang biasa digunakan adalah SD card, seperti pada penelitian (Vojtech, 2011; Nhivekar, 2011; Rudi, 2013; Dutta, 2014)yangmembahas aplikasi data logger dengan dilengkapi SD Card. Hal penting yang perlu diperhatikan adalah bagaimana proses read/write data pada SD card dapat dilakukan. Atas dasar itulah penulis melakukan penelitian yang bertujuan untuk mengetahui karakteristik protokol komunikasi SPI pada data logger yang menggunakan SD card, sehingga proses read/write data pada SD card dapat dilakukan oleh mikrokontroler.

Berdasarkan tujuan penelitian tersebut, maka permasalahan yang dibahas adalah bagaimana menerapkan metoda SPI pada data logger berbasis SD card. Dari pembahasan tersebut dapat diketahui konfigurasi yang harus dilakukan antara mikrokontroler dengan SD card, cara penulisan (write) data pada SD card, cara pembacaan (read) data pada SD card, pengaruh clock pada komunikasi SPI dan pengaruh kapasitas SD card terhadap banyaknya data yang direkam. Untuk keperluan penelitian ini maka penulis merealisasikan sebuah prototype data logger yang dilengkapi SD card, selanjutnya data tersebut dikirimkan menuju Personal Computer (PC) pengguna sistem.

Serial Peripheral Interface (SPI) adalah salah satu protokol komunikasi serial synchronous kecepatan tinggi yang dimiliki oleh ATmega32, karena itulah prototype data logger dibangun dengan menggunakan mikrokontroler ATmega32. Dengan menggunakan AVR 8 bit ini, maka sistem dialokasikan untuk 8 data sensor analog yang disimulasikan dengan resistor variabel. Umumnya data logger bersifat real time dan data sensor yang disimpan dilengkapi dengan data waktu, untuk itu diperlukan komponen RTC untuk memberikan informasi waktu pengambilan data sensor. Data logger ini dilengkapi pula dengan modul Xbee Pro RF sebagai modul wireless, sehingga dapat berfungsi sebagai sistem telemetri dan dapat diaplikasikan pada sistem Wireless Sensor Network (WSN). Karena data logger yang dibangun dapat berfungsi sebagai sistem telemetri,maka pengambilan data dapat dilakukan dari jarak jauh 
secara nirkabel dan dapat diletakkan pada tempat-tempat yang sulit dijangkau ataupun daerah-daerah rawan bencana.

Pada penelitian ini SD card yang terhubung dengan mikrokontroler diformat dengan tipe FAT16 yang merupakan salah satu tipe file system 16 bit. Sedangkan data yang disimpan di dalam SD card berupa sekumpulan paket data sensor yang diambil secara periodikdan disimpan dalam bentuk file dengan format .csv. Hasil penelitian ini selanjutnya dapat dijadikan sebagai dasar untuk menerapkan metoda SPI antara mikrokontroler dengan memori eksternal lainnya.

\section{METODOLOGI PENELITIAN}

\subsection{Gambaran Umum Sistem}

Pada penelitian ini, data logger yang dirancang bertujuan sebagai media pendukung penelitian mengenai karakteristik komunikasi SPI, sehingga data logger yang dibangun memiliki spesifikasi sistem sebagai berikut:

1. Menggunakan mikrokontroler sebagai pengendali.

2. Sumber data pada data logger berasal dari sensor analog. Jumlah pin analog yang dapat digunakan maksimum sebanyak 8 pin dengan resolusi 8-bit.

3. Data yang disimpan dilengkapi dengan informasi waktu.

4. Menggunakan media tanpa kabel (wireless) sebagai pengiriman data antara modul data logger dengan PC.

5. Pengambilan data dilakukan secara periodik.

6. Menggunakan memori eksternal sebagai media penyimpanan data.

7. Komunikasi antara mikrokontroler dan memori eksternal menggunakan komunikasi SPI.

8. Menggunakan catu daya 5 volt.

Berdasarkan spesifikasi sistem yang telah disusun, maka secara umum sistem dapat digambarkan seperti pada Gambar 1.

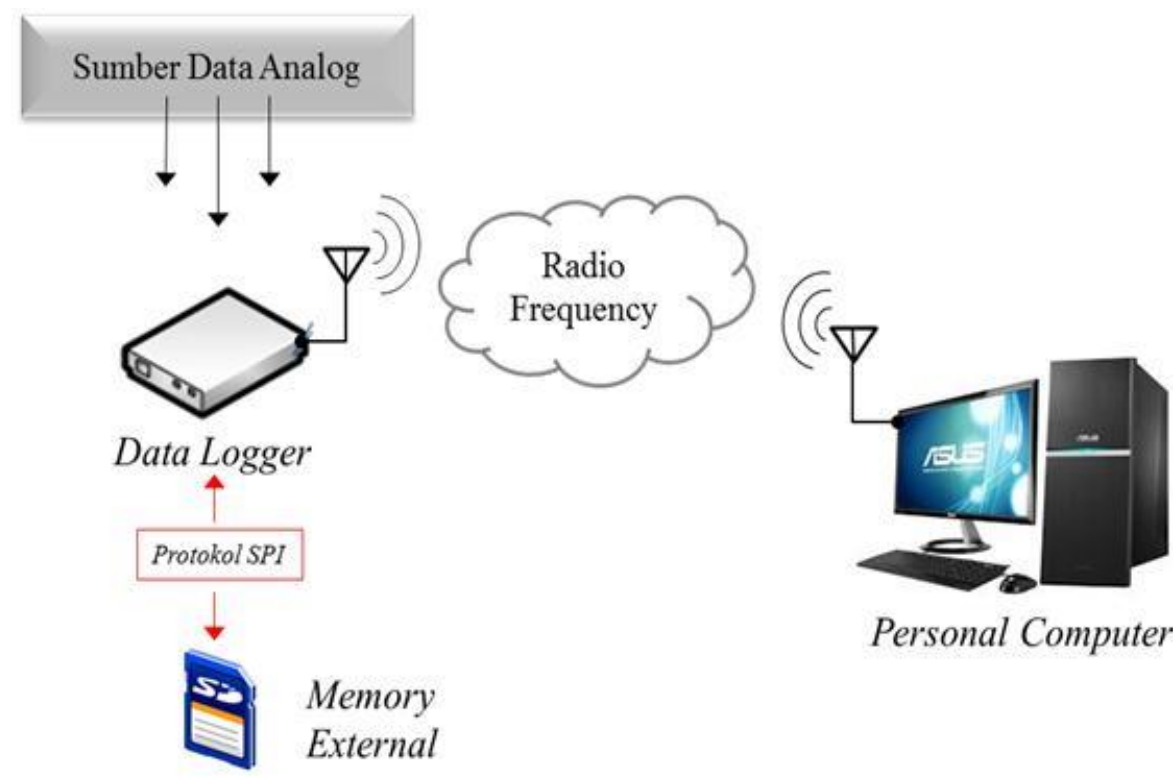

Gambar 1. Gambaran umum system 


\subsection{Perancangan dan Realisasi Hardware}

Berdasarkan spesifikasi yang telah diuraikan maka perlu dirancang perangkat data logger dengan blok diagram pada Gambar 2.

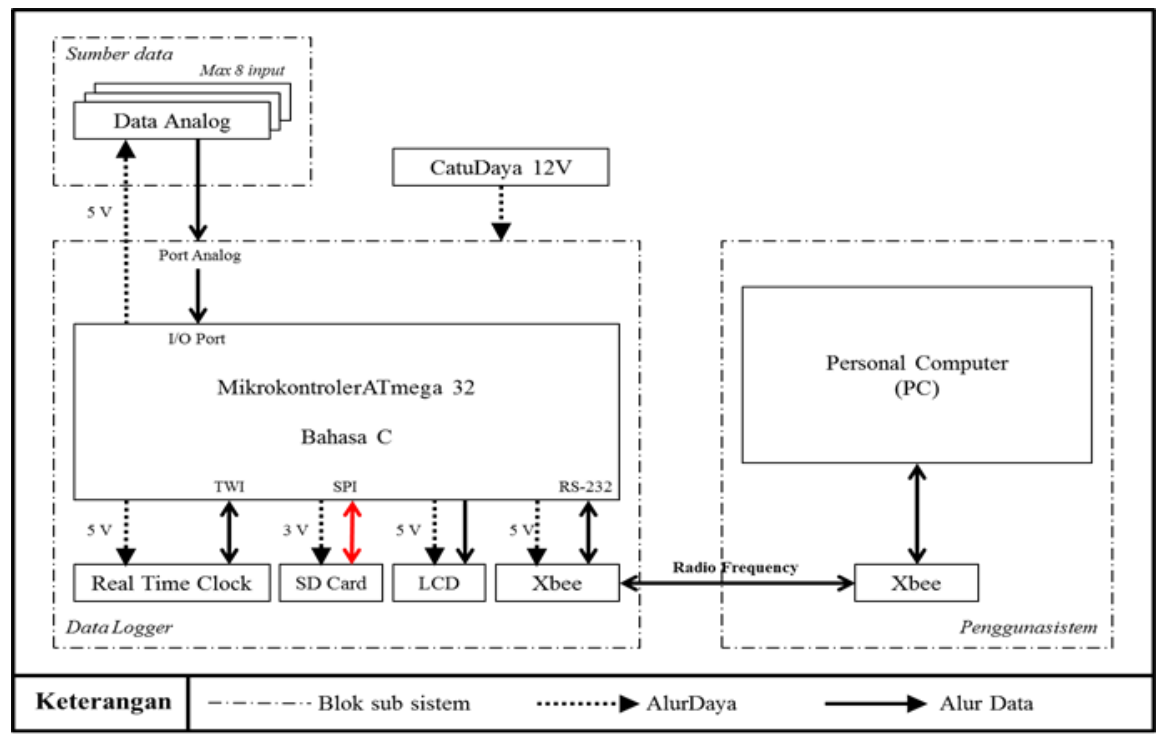

Gambar 2. Blok diagram sistem

Secara keseluruhan sistem terdiri dari 3 sub sistem, yaitu sumber data, data logger, dan pengguna sistem. Sumber data analog yang berasal dari 8 resistor variabel akan diolah oleh mikrokontroler untuk kemudian dicatat dan disimpan pada SD card. Data pada SD card dapat dibaca langsung pada Personal Computer (PC) secara otomatis, yaitu dengan mengirimkan data di dalam SD card ke PC secara nirkabel. Data-data hasil pengukuran dari 8 resistor variabel dan informasi waktu dari RTC akan disimpan pada SD card dalam bentuk file dengan format .csv. Comma Separated Value (CSV) merupakan suatu format file yang berupa nilainilai yang dipisahkan dengan titik koma (;). Konfigurasi rangkaian SD card dengan mikrokontroler dapat dilihat pada Gambar 3.

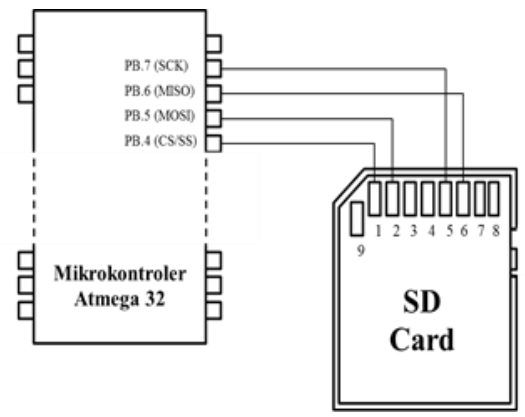

Gambar 3. Rangkaian mikrokontroler dan SD card

Alur pengiriman data dari mikrokontroler sampai ke PC melalui beberapa tahap. Pertamatama data dari mikrokontroler akan dikirimkan secara serial ke modul RF (XBee Pro). Setelah itu pengiriman data antar modul RF transmitter dan modul RFreceiver terjadi secara wireless. Setelah sampai pada modul RF receiver, data diteruskan ke PC menggunakan komunikasi serial. Selanjutnya data yang didapatkan akan ditampilkan pada PC.Sistem transmisi yang digunakan antaradata loggerdan PC terlihat seperti pada Gambar 4. 


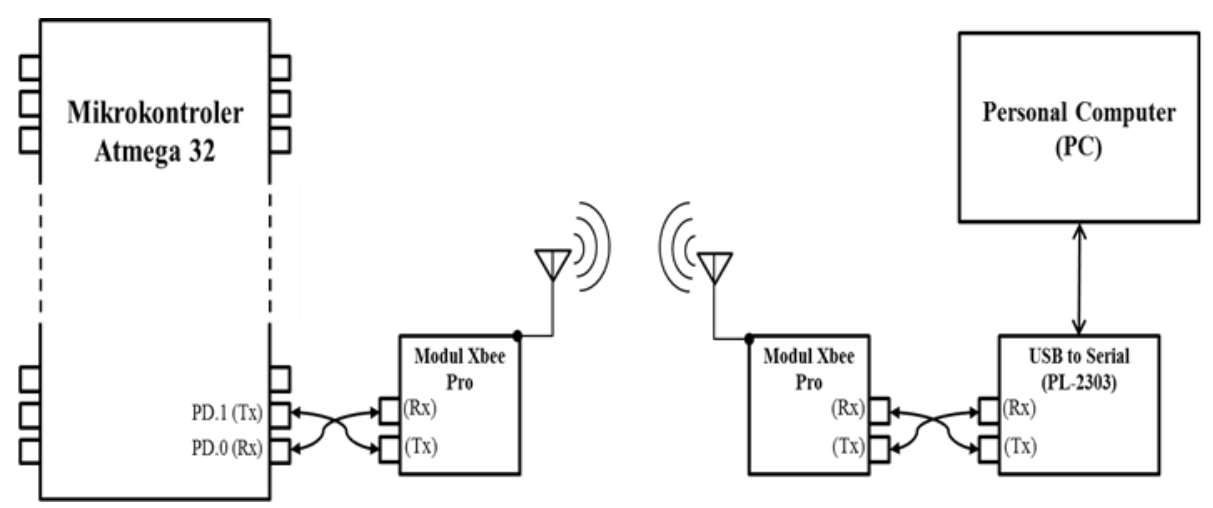

Gambar 4. Sistem Transmisi

Realisasi perangkat keras dilakukan dengan mencetak sistem minimum mikrokontroler ATmega32. Pada board ini terintegrasi pula dengan LCD, RTC, serta catu daya +5 Vdc dan +3 Vdc. Sedangkan hubungan antar mikrokontroler dengan resistor variable, modul SD card dan modul Xbee Pro menggunakan kabel jumper. Realisasi perangkat keras dapat dilihat pada Gambar 5.

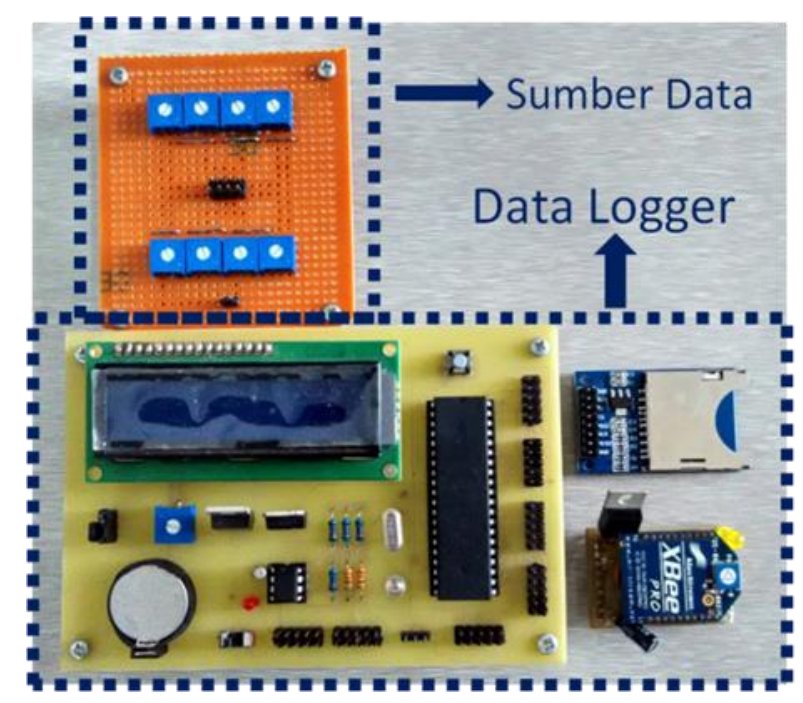

Gambar 5. Realisasi perangkat keras

\subsection{Perancangan dan Realisasi Software}

Perangkat lunak (software) yang digunakan pada penelitian ini ada 3, yaitu software pada pemrograman mikrokontroler menggunakan CodeVision AVR, software pada pemrograman Xbee Pro menggunakan X-CTU, dan software pada Personal Computer (PC) menggunakan Terminal.Program pada mikrokontroler terdiri dari beberapa sub program yaitu inisialisasi, membaca konfigurasi, membaca data dari sensor, menulis dan membaca media penyimpanan serta mengirimkan data ke PC.

Program yang akan ditanamkan pada mikrokontroler mengikuti diagram alir (flowchart) pemrograman untuk data logger seperti terlihat pada Gambar 6. 


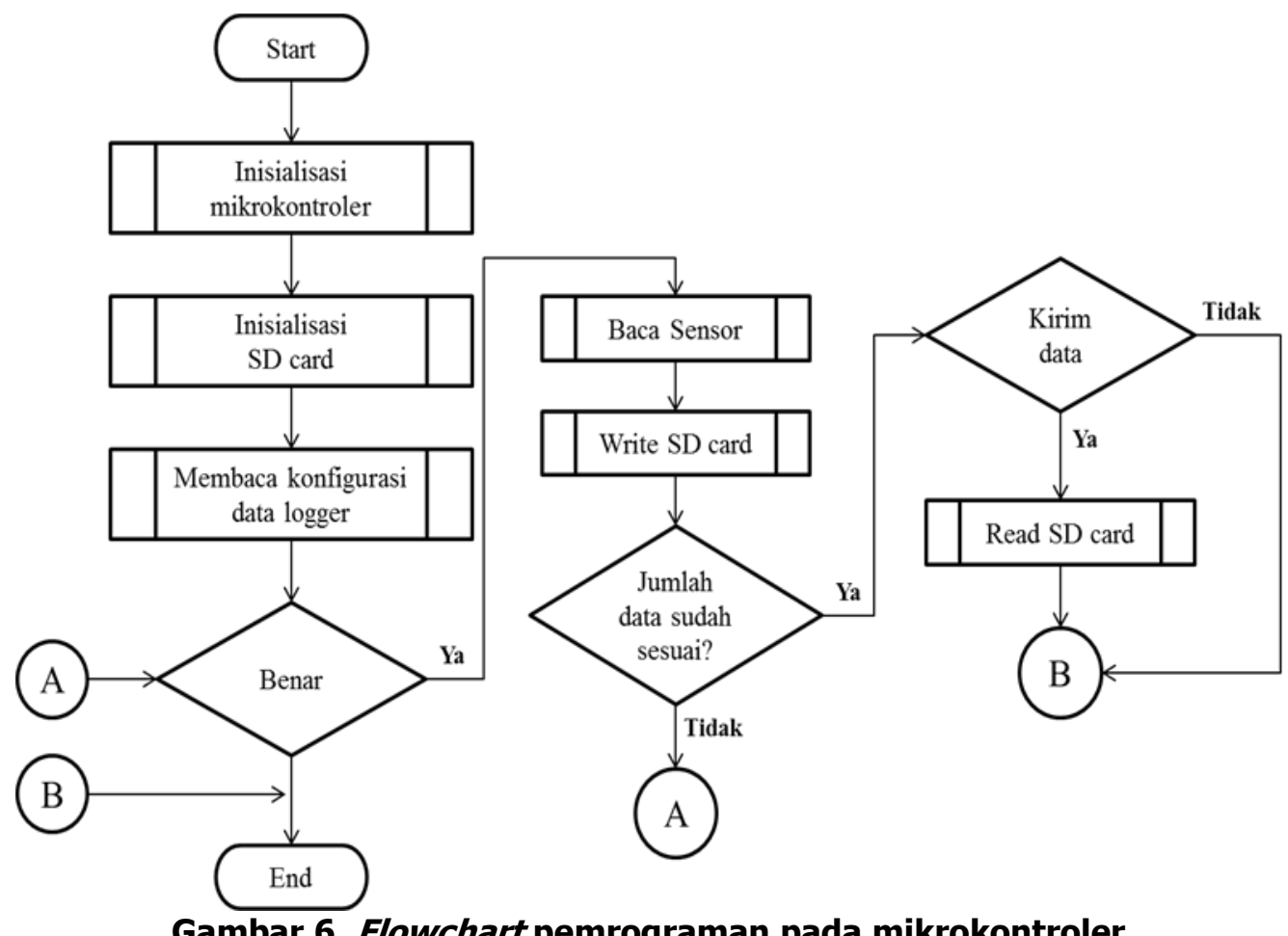

Cara berkomunikasi dengan SD card adalah dengan mengirimkan command kepada SD card dan menerima response dari SD card. SD card command yang terdiri dari 48-bit.

Tabel 1 merupakan penjelasan dari bit command.

Tabel 1. Command untuk SD card

\begin{tabular}{|c|c|c|l|}
\hline Bit Position & Width(bits) & Value & \multicolumn{1}{|c|}{ Name } \\
\hline \hline 47 & 1 & 0 & Start bit \\
\hline 46 & 1 & 1(for command), 0(for response) & Transmission bit \\
\hline $45-40$ & 6 & & Command Number \\
\hline $39-8$ & 32 & & Argument \\
\hline $7-1$ & 7 & & CRC \\
\hline 0 & 1 & 1 & Stop bit \\
\hline
\end{tabular}

Gambar 7 merupakan penjelasan dari bit response.

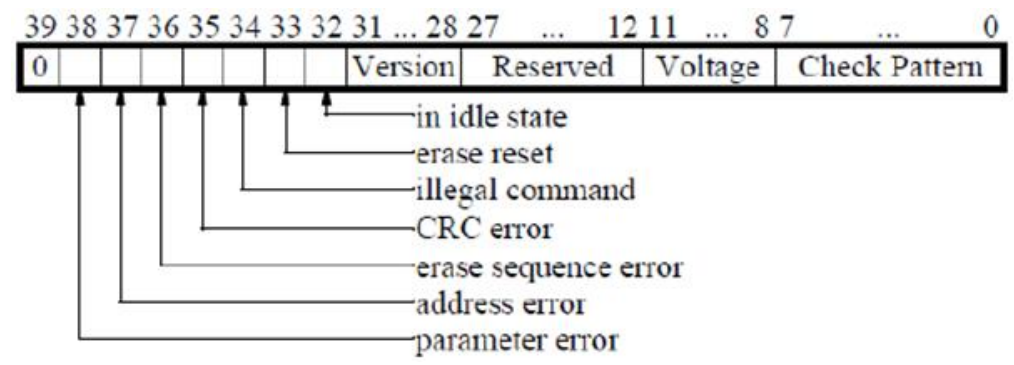

Gambar 7. Response dari SD card

SD card memiliki arsitektur seperti ditunjukkan pada Gambar 8. 


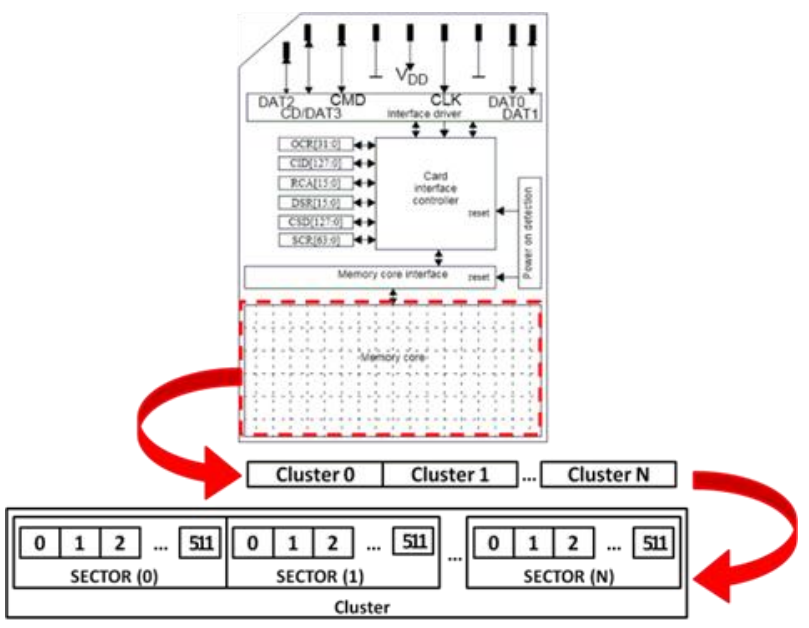

Gambar 8. Arsitektur SD card

Seluruh data file terletak pada Memory core. Memory coreterdiri dari beberapa cluster dan setiap cluster berisi beberapa sektor. Masing-masing sektortersusun dari kumpulan byte dan setiap byte memiliki 8 bit lokasi memori. Format data SD card umumnya menggunakan format File Allocation Table (FAT). FAT12 digunakan untuk kapasitas lebih kecil dari 16 MB. FAT16 digunakan untuk kapasitas 32 MB hingga 2 GB. FAT32 digunakan untuk kapasitas di atas 2 GB (SDHC).

Pada penelitian ini digunakan SD card yang telah diformat dengan tipe FAT16. FAT16 adalah salah satu tipe file sistem 16-bit, yang berarti bahwa alamat cluster tidak dapat lebih besar dari 16-bit. Oleh karena itu jumlah maksimum cluster yang dapat dirujuk dengan sistem FAT16 adalah $2^{16}$ (65536) cluster dengan tiap cluster memiliki beberapa sektor yang masingmasing sektor memiliki kapasitas 512 byte.

Tabel 2. Isi partisi FAT16

\begin{tabular}{|c|}
\hline Reserved Region + Boot Sector \\
\hline File Allocation Table (FAT) Region \\
\hline Root Directory \\
\hline Data Region \\
\hline
\end{tabular}

Berikut ini adalah penjelasan mengenai cara menggunakan SD card dengan FAT16. SD card terbagi atas sektor-sektor dan tiap satu sektornya berisi 512 byte. Secara default, proses baca atau tulis selalu melibatkan satu sektor (512 byte).Hal pertama yang harus dilakukan adalah membaca parameter SD card dengan urutan langkah sebagai berikut:

1. Mengirimkan perintah Reset dan Init ke SD card.

2. Membaca Master Boot Record (berada di sektor 0) untuk mengetahui lokasi Boot Sector. Lalu Boot Sector dibaca secara keseluruhan.

3. Nilai pada alamat-alamat tertentu dari Boot Sector diambil dan dihitung sehingga didapat parameter antara lain: alamat FAT Region, alamat Root Directory, alamat Data Region, jumlah sector per cluster, tipe FAT, dan kapasitas SD card.

Setelah membaca parameter SD card, maka langkah selanjutnya adalah menulis data pada SD card. Urutan langkahnya adalah sebagai berikut:

1. Mengirimkan perintah Reset dan Init ke SD card.

2. Selanjutnyaprogram akan menulis Nama Kartu dan Nama File pada Root Directory. Nilai Root Directory akan dibaca untuk mengetahui posisi sector awal untuk file.Program akan menulis tabel FAT pada FAT Region. 


\section{PENGUJIAN DAN ANALISIS}

\subsection{Metoda Pengujian}

Berdasarkan tujuan pada penelitian ini, metode pengujian yang dilakukan penulis yaitu pengujian mengenai karakteristik dari protokol komunikasi Serial Peripheral Interface (SPI) dan pengujian mengenai data logger. Beberapa tahap pengujian protokol komunikasi SPI, dilakukan dengan menggunakan Logic Analyzer untuk menampilkan sinyal dari beberapa pin yang akan diamati. Beberapa tahap pengujian lainnya dilakukan melalui pengamatan data pada PC.

Logic analyzer adalah perangkat elektronik yang dapat meng-capture beberapa sinyal dari sistem digital atau rangkaian digital. Selain dapat meng-capture sinyal, Logic analyzer juga dapat menampilkan data sinyal yang telah di-capture ke dalam PC. Gambar 8 adalah Logic analyzer yang digunakan dalam pengujian ini.

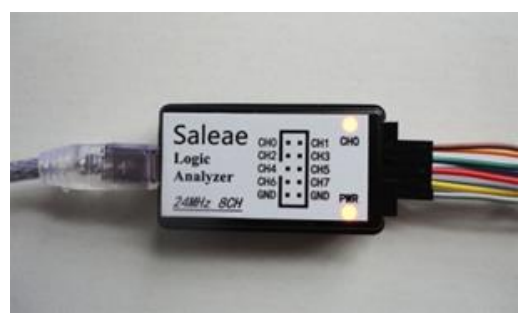

Gambar 9. Logic Analyzer

Logic analyzer pada pengujian ini menggunakan tipe Saleae Logic Analyzer yang memiliki 8 buah kanal. Alat ini digunakan untuk meng-capture dan menampilkan sinyal dari beberapa pin yang digunakan dalam komunikasi SPI yaitu Slave Select $(\overline{S S})$, Master Input / Slave Output (MISO), Master Output / Slave Input (MOSI), dan Serial Clock(SCK).

\subsection{Pengujian Serial Peripheral Interface (SPI)}

Sebelum melakukan pengujian sistem data logger, terlebih dahulu dilakukan pengujian protokol komunikasi Serial Peripheral Interface (SPI) pada komunikasi antar mikrokontroler dengan SD card. Pengujian ini bertujuan untuk mengetahui karakteristik dari protokol komunikasi SPI yang terjadi antar mikrokontroler dengan SD card.

\subsubsection{Pengujian konfigurasi Mikrokontroler dan SD card}

Pengujian ini bertujuan untuk mengetahui konfigurasi SPI yang dapat digunakan dalam komunikasi mikrokontroler dan SD card. Pada pengujian ini dilakukan inisialisasi SD card oleh mikrokontroler dengan program reset dan init SD card.

\section{a. One Slave Configuration}

One slave configuration adalah konfigurasi 1 (satu) Master dengan 1 (satu)Slave. Pada pengujian ini mikrokontroler sebagai Master dan SD card sebagai Slave. SD card yang digunakan memiliki kapasitas sebesar 256 MB. Gambar 10 menunjukkan rangkaian One Slave Configuration. 


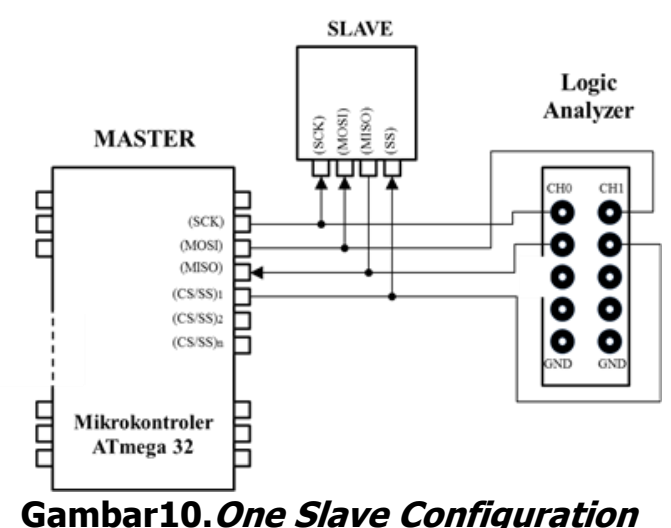

\section{Reset SD card}

Gambar 11 adalah timing diagram program reset SD card.

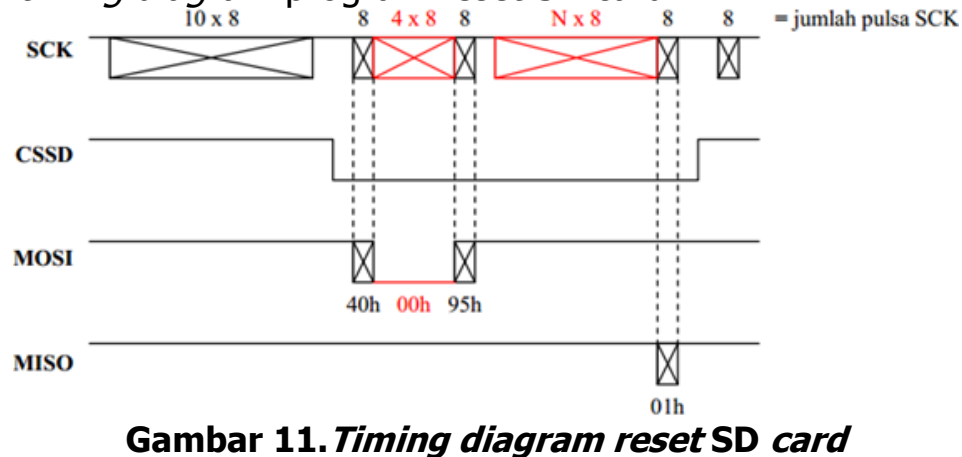

Hasil pengujian dengan program reset dapat dilihat pada Gambar 12.

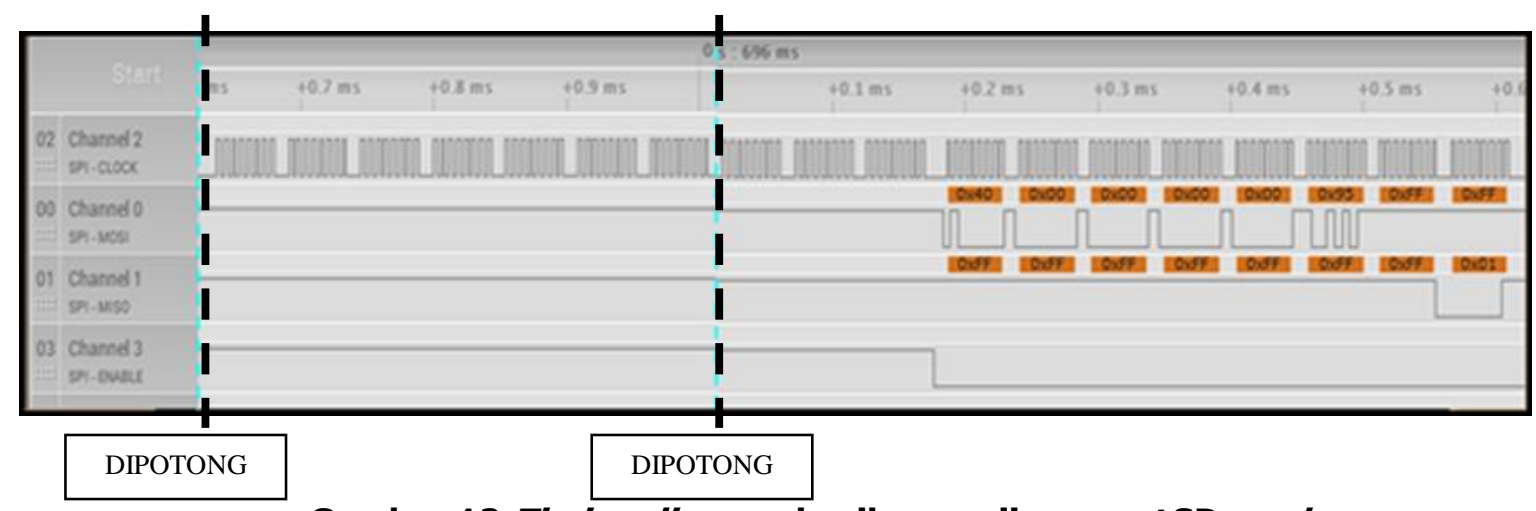

Gambar 12. Timing diagram hasil pengujian reset SD card

Gambar 12 menunjukkan bahwa sinyal MOSI dari mikrokontroler mengirimkan sinyal resetcommand (400000000095h) kepada SD card. Pin MISO yang bernilai 01h menyatakan bahwa perintah reset ini sudah diterima oleh SD card. Hasil pengujian ini telah sesuai dengan Timing diagram reset SD card pada Gambar 11, artinya SD card telah terinisialisasi ke dalam mode SPI.

\section{Init SD card}

Gambar 13 adalah timing diagram program init SD card. 


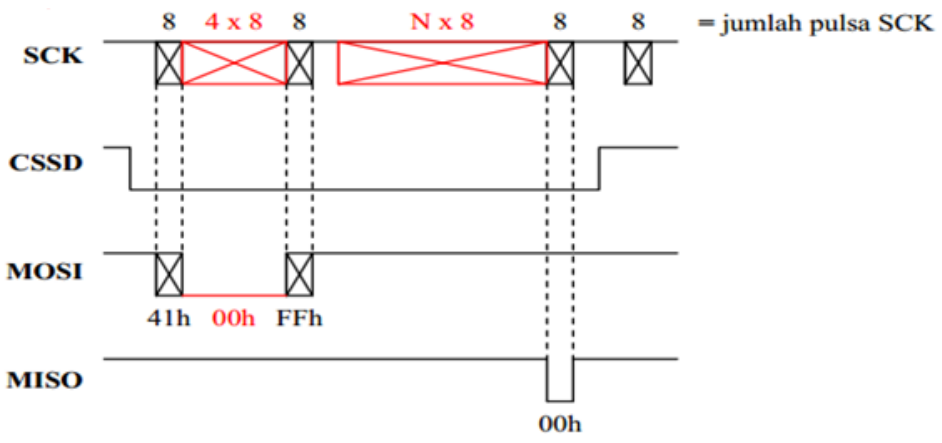

Gambar 13. Timing diagram init SD card

Hasil pengujian dengan program init dapat dilihat pada Gambar 14.

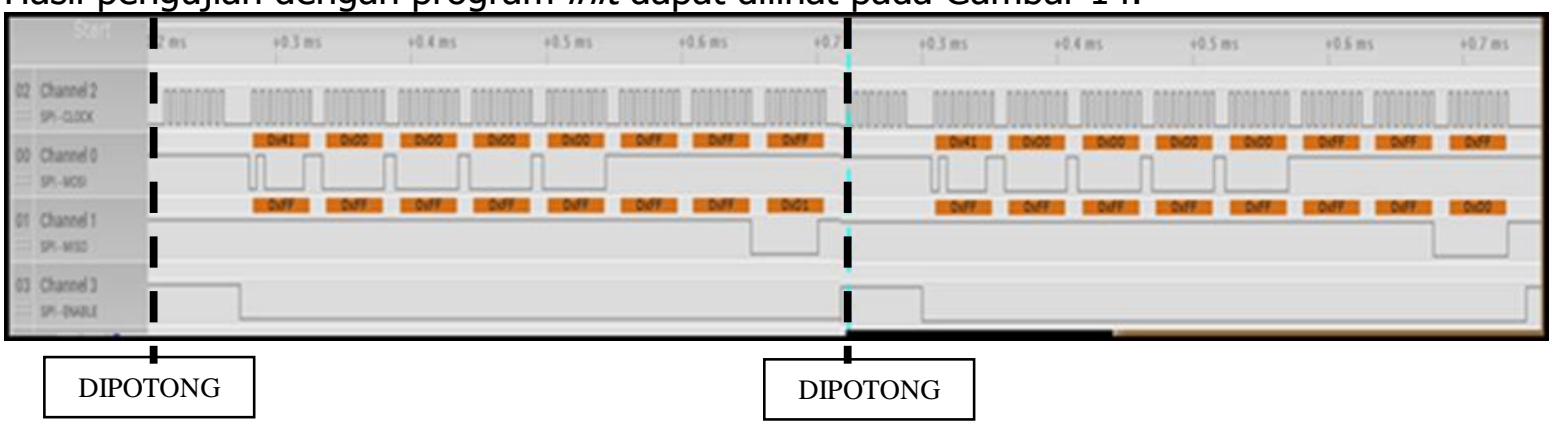

Gambar 14. Timing diagram hasil pengujian init SD card

Gambar 14 menunjukkan bahwa sinyal MOSI pada mikrokontroler mengirimkan sinyal init command (4100000000FFh) kepada SD card. Pin MISO yang bernilai 00h menyatakan bahwa SD card telah terinisialisasi. Hasil pengujian ini telah sesuai dengan timing diagraminit SD card (Gambar 13), artinya SD card telah terinisialisasi dan siap untuk menerima command selanjutnya.

\section{b. Multiple Slaves Configuration}

Multiple Slaves Configuration adalah konfigurasi 1 (satu) Master dengan lebih dari 1 (satu) Slave. Pada pengujian ini mengkonfigurasikan 2 (dua) SD card dengan masing-masing memiliki kapasitas sebesar 256 MB dan 2 GB. Konfigurasi Multiple Slaves pada SPI terdapat 2 (dua) macam yaitu Independent Slave Configuration dan Daisy Chain Configuratio.

\section{Independent Slave Configuration}

Gambar 15 menunjukkan rangkaian Independent Slave Configuration.

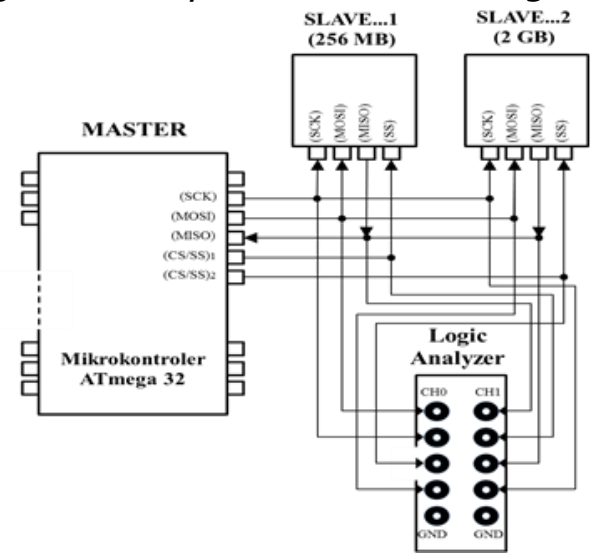

Gambar 15.Independent Slave Configuration 
Hasil pengujian Independent Slave Configuration dapat dilihat pada Gambar 16.

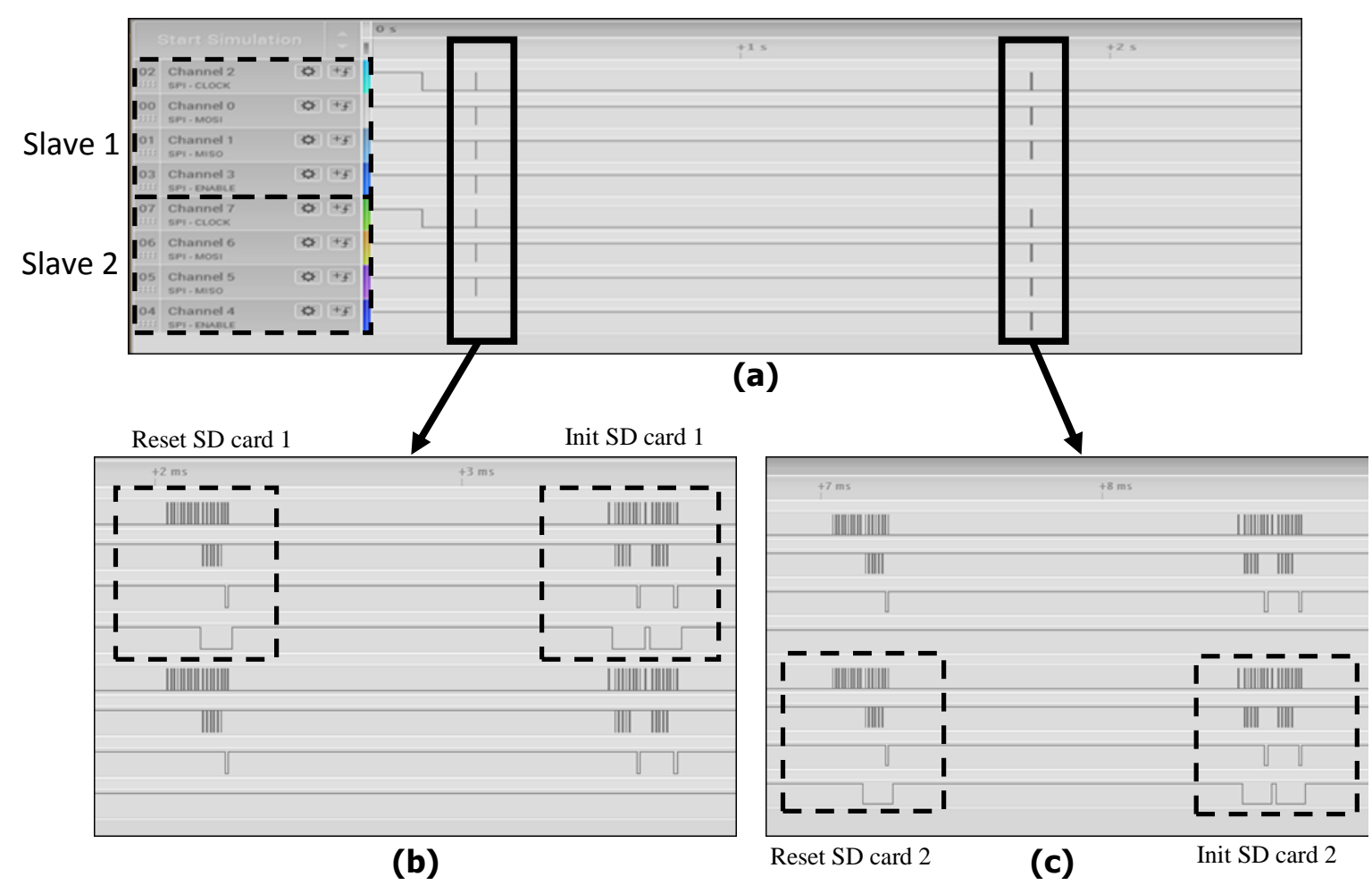

Gambar 16. (a) Hasil inisialisasi Independent Slave Configuration;(b) Hasil inisialisasi SD card 1; (c) Hasil inisialisasi SD card 2

Pada Gambar 16, mikrokontroler melakukan proses inisialisasi pada masing-masing Slave secara bergantian dengan cara memberi logika low pada pin CSSD SD card yang akan diakses. Dan masing-masing Slave telah terinisialisasi dan dapat digunakan sebagai media penyimpanan data.

\section{Daisy Chain Configuration}

Gambar 17 menunjukkan rangkaian Daisy Chain Configuration.

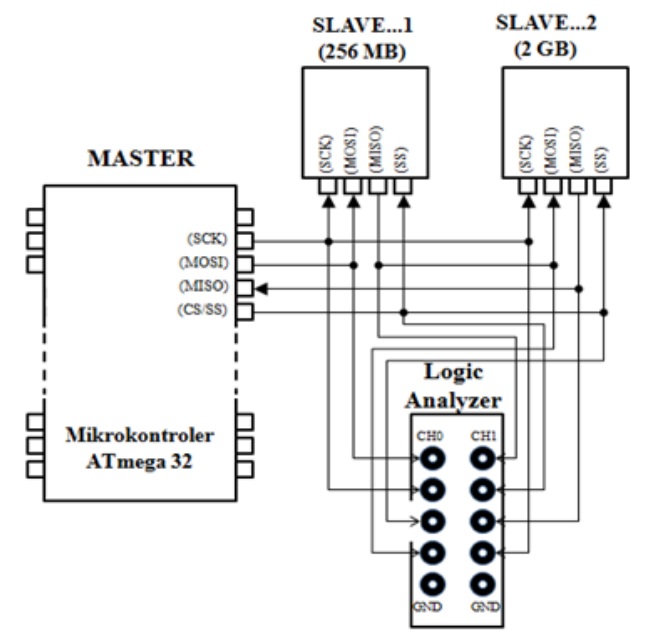

Gambar 17. Daisy Chain Configuration 
Hasil pengujian Daisy Chain Configuration dapat dilihat pada Gambar 18.

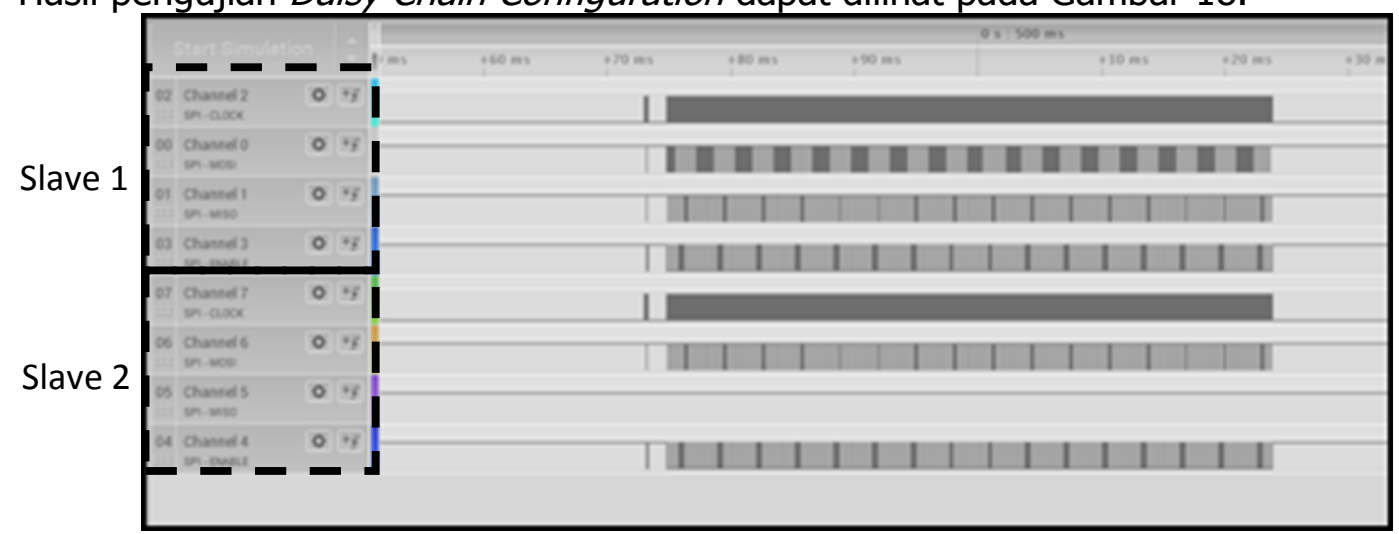

Gambar 18. Hasil inisialisasi Daisy Chain Configuration

Pada Gambar 18 terjadi pemeriksaan berulang dikarenakan sinyal MISO dari Slave 1 tidak terhubung dengan mikrokontroler melainkan terhubung ke MOSI pada Slave 2. Hubungan ini menyebabkan mikrokontroler tidak menerima informasi mengenai proses inisialisasi SD card sehingga terjadi pengulangan sampai batas maksimal.

Dari hasil pengujian Multiple Slave Configuration dapat diambil kesimpulan bahwa Independent Slave Configuration dapat digunakan untuk komunikasi SPI antar mikrokontroler dengan SD card sedangkan Daisy Chain Configuration tidak dapat digunakan untuk komunikasi SPI antar mikrokontroler dengan SD card.

\subsubsection{Pengujian Read / Write data pada SD card}

Pada pengujian read/write data SD card, dilakukan pemrograman pada mikrokontroler mengikuti flowchart pada Gambar 19.

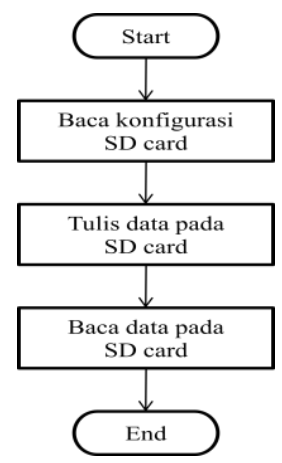

\section{Gambar 19. Flowchart pengujian read/write data pada SD card}

\section{a. One Slave Configuration}

1) Read konfigurasi SD card

Sub program ini bertujuan untuk mengetahui konfigurasi mengenai SD card sehingga data yang ditulis dapat dibaca oleh mikrokontroler maupun PC. Gambar 20 adalah sinyal dari program read konfigurasi.

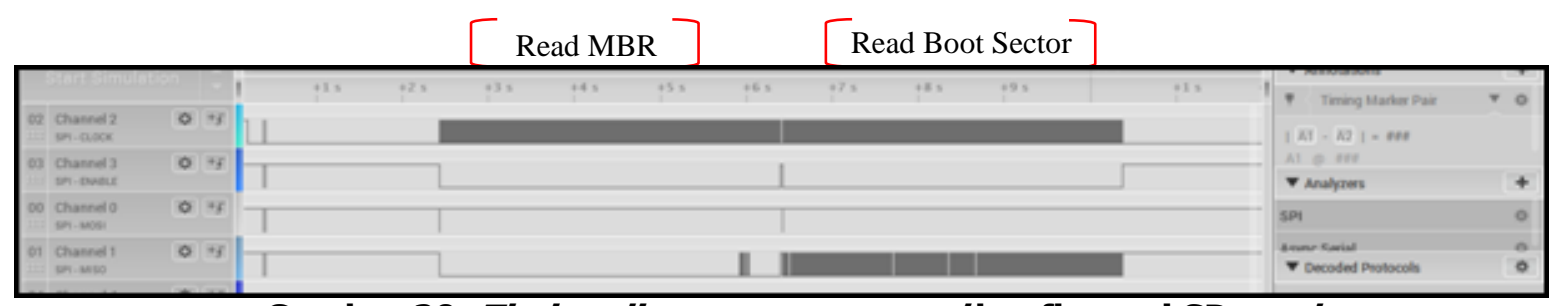

Gambar 20. Timing diagram proses read konfigurasi SD card 
Gambar 21adalah gambar hasil pembacaan Master Boot Record dan Boot Sector.

\begin{tabular}{|c|c|c|c|c|c|c|c|}
\hline \multicolumn{8}{|c|}{ I. Terminal v1.9b - 20080315B - by Br@y++ } \\
\hline Disconnect & COM Port & \multirow{5}{*}{ 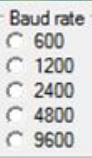 } & \multirow{5}{*}{$\begin{array}{l}C 14400 \\
C \quad 19200 \\
C \quad 28800 \\
C \quad 38400 \\
C \quad 56000\end{array}$} & \multirow{5}{*}{$\begin{array}{ll}C & 57600 \\
\text { C. } & 115200 \\
C & 128000 \\
C & 256000 \\
r & \text { custom }\end{array}$} & \multirow{5}{*}{ 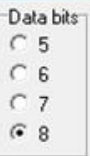 } & \multirow{5}{*}{$\begin{array}{l}\text { Parity } \\
C \text { none } \\
C \text { odd } \\
C \text { even } \\
C \text { mark } \\
C \text { space }\end{array}$} & \multirow{5}{*}{$\begin{array}{l}\text { Stop bits } \\
\text { < } 1 \\
<1.5 \\
\subset 2\end{array}$} \\
\hline Rescan & COM14 $=$ & & & & & & \\
\hline Help & & & & & & & \\
\hline About. & $\mathrm{COMs}$ & & & & & & \\
\hline Quit & & & & & & & \\
\hline \multicolumn{8}{|l|}{$\begin{array}{l}\text { Settings } \\
\text { Receive }\end{array}$} \\
\hline \multicolumn{8}{|c|}{ Configuration of $\mathrm{SD}$ card } \\
\hline Boot Sector & $: 101$ & & & & & & \\
\hline FAT Region & 109 & & & & & & \\
\hline Root Directory & 597 & & & & & & \\
\hline Data Region & 629 & & & & & & \\
\hline Sector of Cluster & $r: 8$ & & & & & & \\
\hline Byte of Sector & $: 512$ & & & & & & \\
\hline Type & FAT 16 & & & & & & \\
\hline Size card (MB) & 243 & & & & & & \\
\hline
\end{tabular}

Gambar 21. Tampilan beberapa parameter MBR dan Boot Sector

2) Write data pada SD card

Sub progam ini bertujuan untuk melakukan penulisan datapada SD card oleh mikrokontroler dengan komunikasi SPI.Gambar 22 merupakan Timing diagram dari program write data pada SD card.

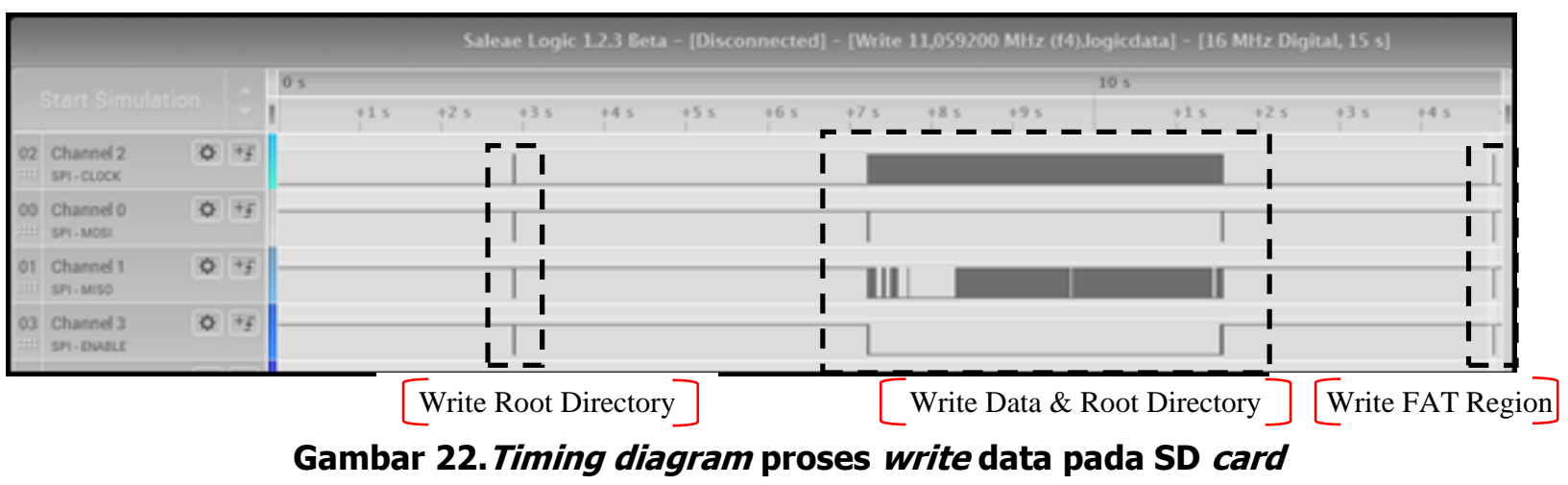

Gambar 23 menunjukkan pembacaan Root Directory hasil penulisan pada software WinHex.

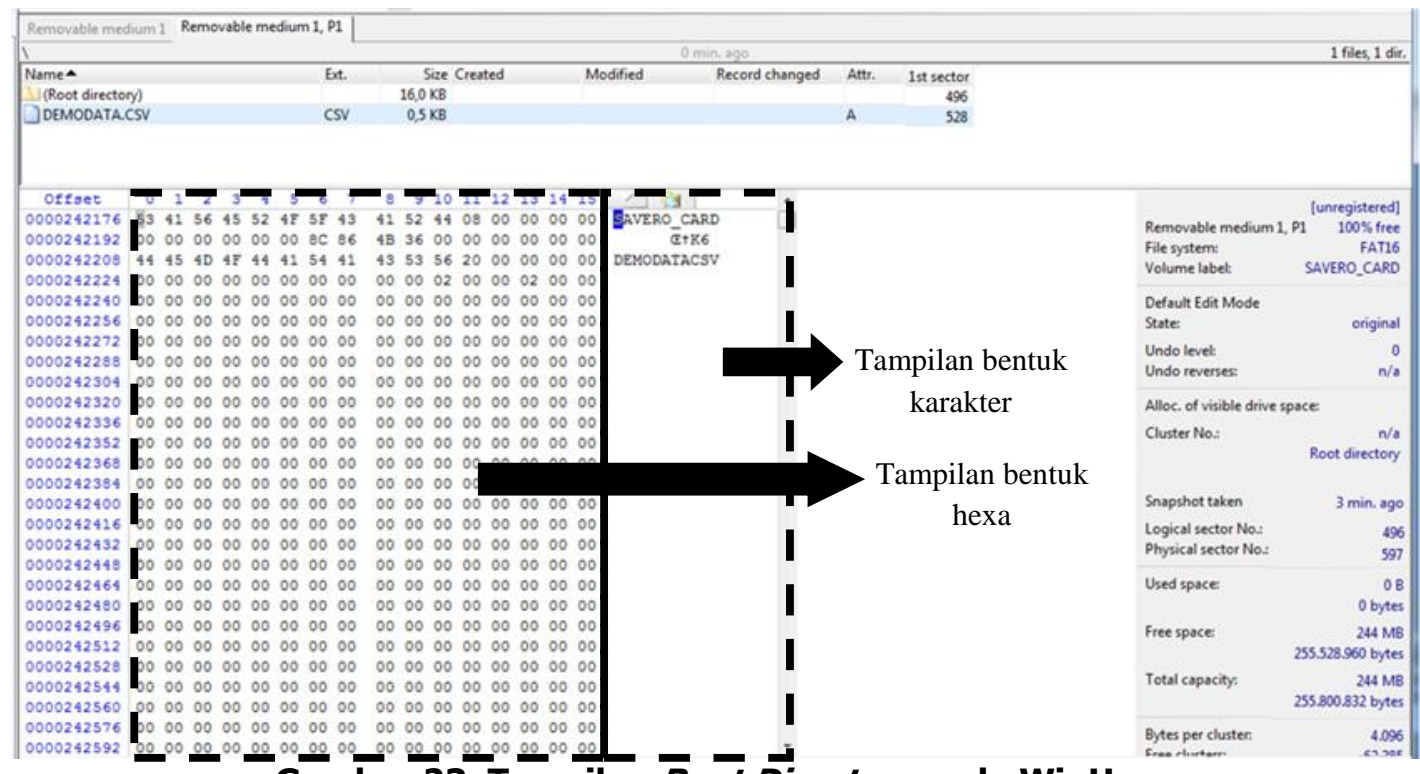

Gambar 23. Tampilan Root Directory pada WinHex 
Penerapan metoda Serial Peripheral Interface (SPI) pada rancang bangun Prototype Data Logger berbasis SD card sebagai Sistem Telemetri

Gambar 24 menunjukkan pembacaan Data Region hasil penulisan pada software WinHex.

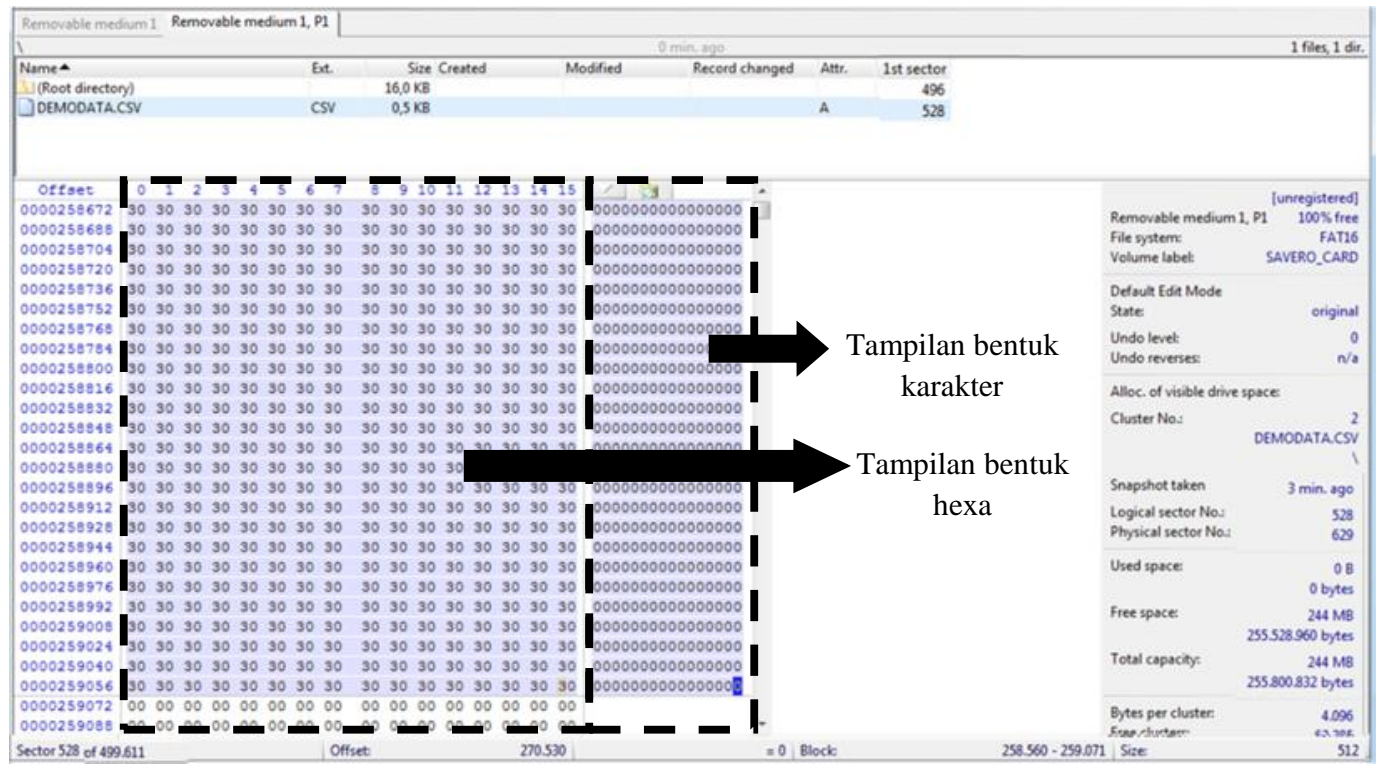

Gambar 24. Tampilan Data Regionpada WinHex

Gambar 25 menunjukkan pembacaan FAT Region hasil penulisan pada software WinHex.

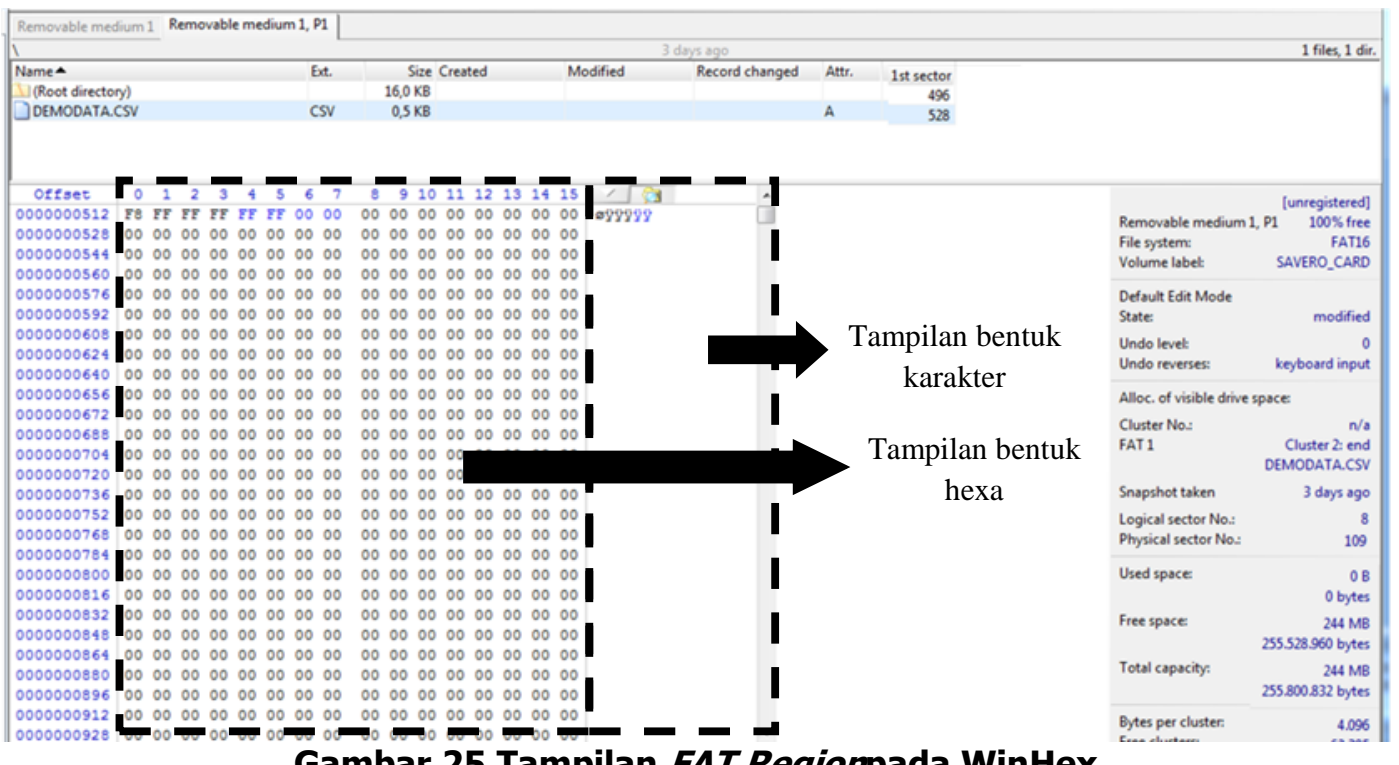

3) Read data pada SD card

Gambar 25.Tampilan FAT Regionpada WinHex

Sub program ini bertujuan untuk melakukan pembacaan data sebanyak 512 byte pada SD card oleh mikrokontroler dengan komunikasi SPI dan mengirimkan data tersebut ke PC.Gambar 26 merupakan Timing diagram dari program read data pada SD card.

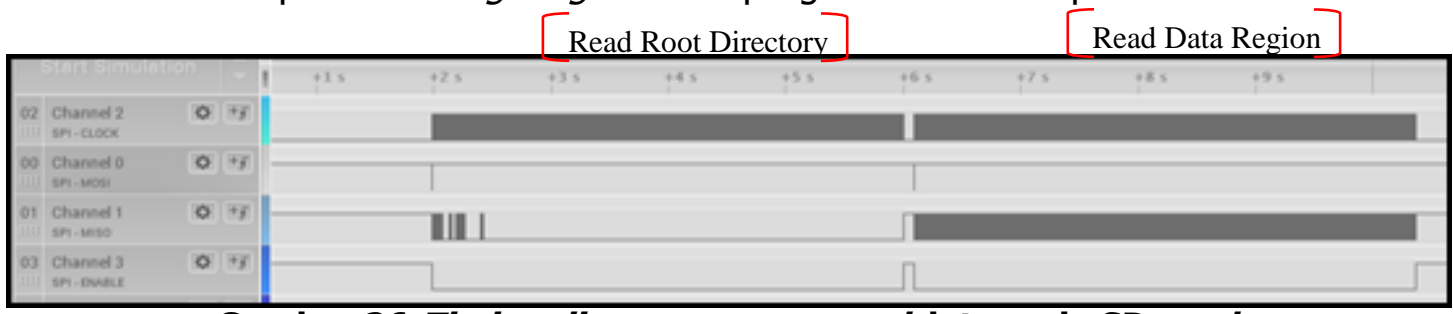

Gambar 26. Timing diagram proses read data pada SD card 
Gambar 27 dan 28 merupakan perbandingan hasil pembacaan data pada aplikasi Terminal pada PC dan pembacaanfile isi SD card secara langsung pada PC.

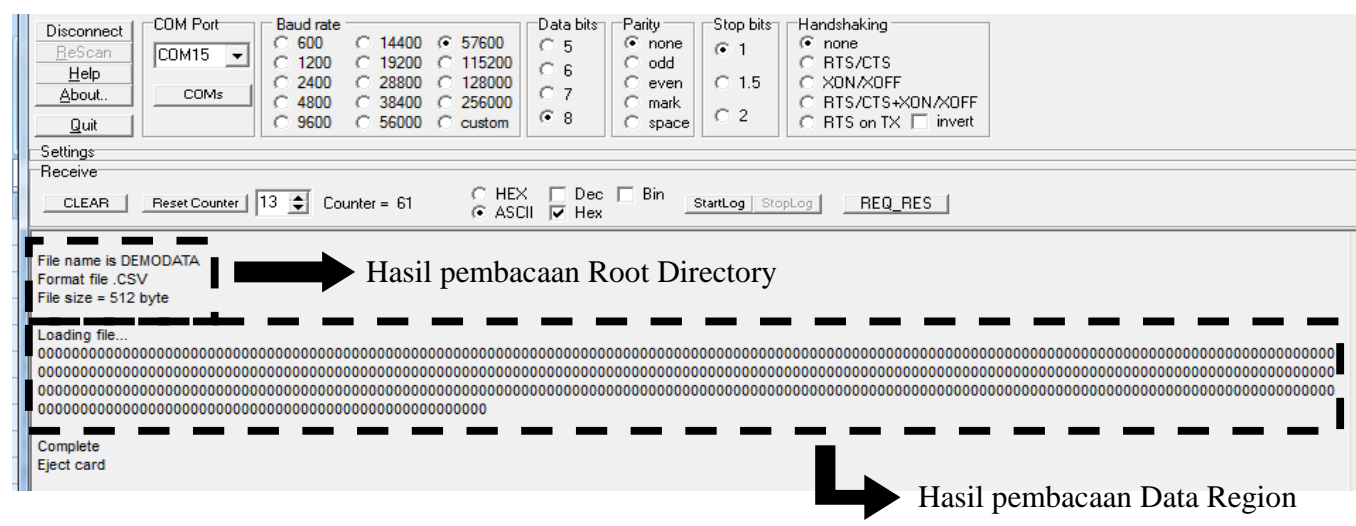

Gambar 27. Pembacaan pada Terminal

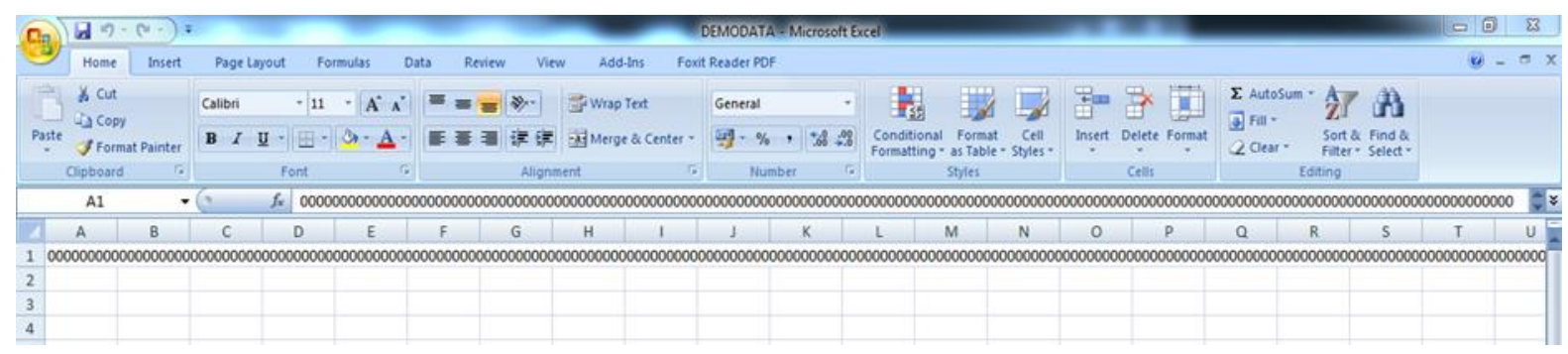

Gambar 28. Pembacaan pada Excel

b. Multiple Slaves Configuration

Pada pengujian read/write Multiple Slaves Configuration, hanya dilakukan dengan menggunakanIndependent Slave Configuration dikarenakan Daisy Chain Configuration tidak dapat digunakan untuk komunikasi antara mikrokontroler dengan SD card. Gambar 29 merupakan hasil pembacaan MBR dan Boot Sector pada 2 SD card.

\begin{tabular}{|ll}
\hline Reading: & \\
& \\
SD card 1 & $: 101$ \\
Boot Sector & $: 109$ \\
FAT Region & $: 597$ \\
Root Directory & $: 629$ \\
Data Region & $: 8$ \\
Sector of Cluster & $: 812$ \\
Byte of Sector & $: 512$ \\
Type & $:$ FAT16 \\
Size card (MB) & $: 243$ \\
& \\
SD card 2 & \\
Boot Sector & $: 129$ \\
FAT Region & $: 131$ \\
Root Directory & $: 609$ \\
Data Region & $: 641$ \\
Sector of Cluster & $: 64$ \\
Byte of Sector & $: 512$ \\
Type & $:$ FAT16 \\
Size card (MB) & $: 1909$ \\
Read complete & \\
\hline
\end{tabular}

Gambar 29.Tampilan beberapa parameter MBR dan Boot Sectordari 2 SD card 
Gambar 30 adalah hasil pembacaan data pada aplikasi Terminal pada PC.

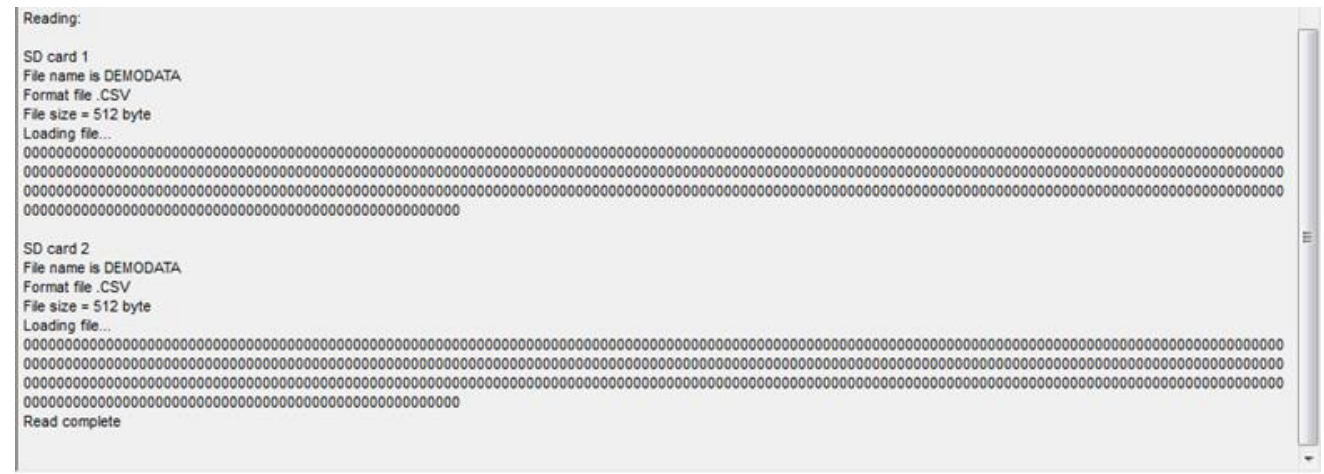

Gambar 30.Pembacaan data 2 SD card pada Terminal

\subsubsection{Pengujian nilai clock}

Pengujian ini bertujuan mengetahui pengaruh nilai clock terhadap waktudalam komunikasi SPI antar mikrokontroler dengan SD card saat melakukan read/write data sebanyak 512 byte.Hasil pengujian mengenai nilai clock dapat dirangkum dalam bentuk tabel seperti pada tabel 3.

\section{Tabel 3. Hasil pengujian nilai clock}

\begin{tabular}{|c|c|c|c|c|c|c|c|c|c|c|c|c|c|c|c|c|c|c|}
\hline \multirow{3}{*}{$\begin{array}{l}\text { Clock } \\
\text { Frequency }\end{array}$} & \multicolumn{3}{|c|}{ stal $4 \mathrm{MHz}$} & \multicolumn{3}{|c|}{ Crystal $8 \mathrm{MHz}$} & \multicolumn{3}{|c|}{ Crystal $11.059200 \mathrm{MHz}$} & \multicolumn{3}{|c|}{ Crystal $12 \mathrm{MHz}$} & \multicolumn{3}{|c|}{ Crystal $16 \mathrm{MHz}$} & \multicolumn{3}{|c|}{ rystal $20 \mathrm{MHz}$} \\
\hline & \multirow{2}{*}{ Avg. Freq. } & \multicolumn{2}{|c|}{ Time (s) } & \multirow{2}{*}{ Avg Freq. } & \multicolumn{2}{|c|}{ Time (s) } & \multirow{2}{*}{ Avg Freq. } & \multicolumn{2}{|c|}{ Time (s) } & \multirow{2}{*}{ Avg Freq } & \multicolumn{2}{|c|}{ Time (s) } & \multirow{2}{*}{ Avg Freq } & \multicolumn{2}{|c|}{ Time (s) } & \multirow{2}{*}{ Avg Freq } & \multicolumn{2}{|c|}{ Time (s) } \\
\hline & & Write & Read & & Write & \begin{tabular}{|l|} 
Read \\
\end{tabular} & & Write & Read & & Write & \begin{tabular}{|l|} 
Read \\
\end{tabular} & & Write & Read & & Write & Reac \\
\hline $1 / 2$ & & 12.05 & 7.636 & & 12.06 & \begin{tabular}{|c|}
7.633 \\
\end{tabular} & & 12.02 & 7.649 & & 12.06 & 7.682 & 2529.0 & 12.1 & 7.723 & & 2.05 & 1.08 \\
\hline $1 / 4$ & & & 7. & & 12.06 & 7.6 & & .01 & 7.6 & & .06 & 7.6 & & 11 & 7.7 & & .08 & + \\
\hline $1 / 8$ & & & 7.6 & & 04 & 7.6 & & 03 & 7.6 & & 12.07 & 7.6 & & .17 & 7.1. & & 2.05 & 1.0 \\
\hline tal / $/ 1$ & & 108 & 7.639 & & 12.06 & 7.632 & & 12.04 & \begin{tabular}{|l||}
7.651 \\
\end{tabular} & 51.7 & 12.06 & 7.682 & 000 & 12.12 & 7.724 & & 12.06 & 7.68 \\
\hline $\mathrm{ystal} / /$ & & 12.09 & 7.64 & & 12.09 & 7.633 & & 12.06 & 7.653 & 8 & 12.08 & 7.684 & 00 & 12.16 & 7.756 & 25.7 & 12.08 & 7.68 \\
\hline rystal / 6 & & 12.13 & 7.647 & & 12.09 & 7.635 & & 12.11 & 7.657 & 187.6 & 12.13 & \begin{tabular}{|c|}
7.687 \\
\end{tabular} & 25 & 12.19 & 7.758 & & 12.1 & 68 \\
\hline ystal / 128 & .25 & 12.22 & 7.649 & 53 & 12.23 & 7.645 & 86.42 & 12.21 & 7.663 & 93.72 & 12.22 & 7.694 & 125 & 12.2 & 7.766 & 156.2 & 12.15 & 7.6 \\
\hline
\end{tabular}

Berdasarkan hasil pengujian pada Tabel 3 dapat ditarik kesimpulan bahwa semua crystal yang terdapat di pasaran dapat digunakan untuk komunikasi SPI antara mikrokontroler ATmega32 dengan SD card menggunakan format FAT16.

Setelah pengujian protokol komunikasi SPI dilakukan, maka didapat beberapa kesimpulan mengenai karakteristik dari protokol komunikasi SPI yang terjadi antar mikrokontroler dengan SD card. Beberapa kesimpulan tersebut adalah:

1. Agar Master dapat berkomunikasi dengan Slave, maka Master perlu memberi logika low pada pin CSSD. Apabila digunakan lebih dari 1 Slave, maka Master perlu member logika Iow pada pin CSSD dari Slave yang akan diajak berkomunikasi dan memberi logika high pada pin CSSD dari Slave lainnya.

2. Pada pegujian protokol komunikasi SPI antar mikrokontroler dengan SD card menggunakan beberapa command, yaitu reset command (CMD0), init command (CMD1), read command (CMD17), dan write command (CMD24).

3. Berdasarkan Tabel 3 dapat disimpulkan bahwa crystal $4 \mathrm{MHz}-20 \mathrm{MHz}$ dapat digunakan untuk komunikasi SPI antara mikrokontroler dengan SD card dengan masing-masing nilai clockdarisetiap crystaladalah crysta//2 - crystal/128. 


\subsection{Pengujian Data Logger}

Pengujian data logger dilakukan agar dapat mengetahui bahwa sistem telah direalisasikan dengan benar dan dapat mendukung penelitian ini. Pengujian sistem data logger dilakukan dengan pengujian keseluruhan sistem data logger mengikuti diagram alir dari sistem data logger yang telah dirancang seperti pada Gambar 5. Pengujian ini meliputi pengiriman data secara wireless dan pengujian kapasitas data SD card yang dapat diisi berdasarkan waktu tertentu.

Pada pengujian mengenai data loggerdilakukan perekaman data 8 (delapan) resistor variabel ke dalam SD card berkapasitas 2 GB. Perangkat data logger diletakkan berjarak 5 meter dari PC dan pengiriman data dilakukan secara wireless.Tabel4 dan 5 adalah penjelasan dari format satu paket datayang terdiri dari 59 byte.

Tabel 4.Format Paket Data Baris Pertama

\begin{tabular}{|l||c|c|c|c|c|c|c|c|c|c|}
\hline \multicolumn{1}{|c|}{ Baris pertama } \\
\hline \hline Keterangan & Date & Time & Data1 & Data2 & Data3 & Data4 & Data5 & Data6 & Data7 & Data8 \\
\hline Jumlah byte & 4 byte & 4 byte & 5 byte & 5 byte & 5 byte & 5 byte & 5 byte & 5 byte & 5 byte & 5 byte \\
\hline
\end{tabular}

Tabel 5.Format Paket Data Baris Kedua sampai baris ke-n

\begin{tabular}{|l||c|c|c|c|c|c|c|c|c|c|}
\hline \multicolumn{10}{|c|}{ Baris kedua hingga baris ke-n } \\
\hline \hline Format data & dd/mm/yy & hh:mm:ss & x.xV & x.xV & x.xV & x.xV & x.xV & x.xV & x.xV & x.xV \\
\hline Jumlah byte & 8 byte & 8 byte & 4 byte & 4 byte & 4 byte & 4 byte & 4 byte & 4 byte & 4 byte & 4 byte \\
\hline
\end{tabular}

Note : karakter ';' digunakan untuk memisahkan antar kolom karakter ' $\mid \mathrm{n}$ ' dan ' $\mathrm{r}$ ' digunakan untuk mengakhiri baris

Gambar 31 merupakan hasil pengujian selama 1 menit dengan skala periodik pengambilan data setiap 1 detik.

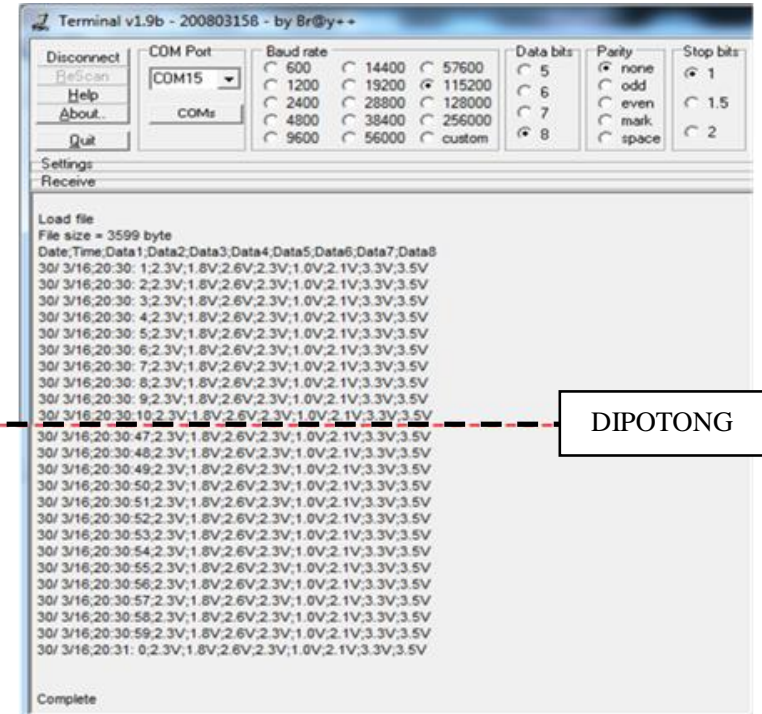

(a)

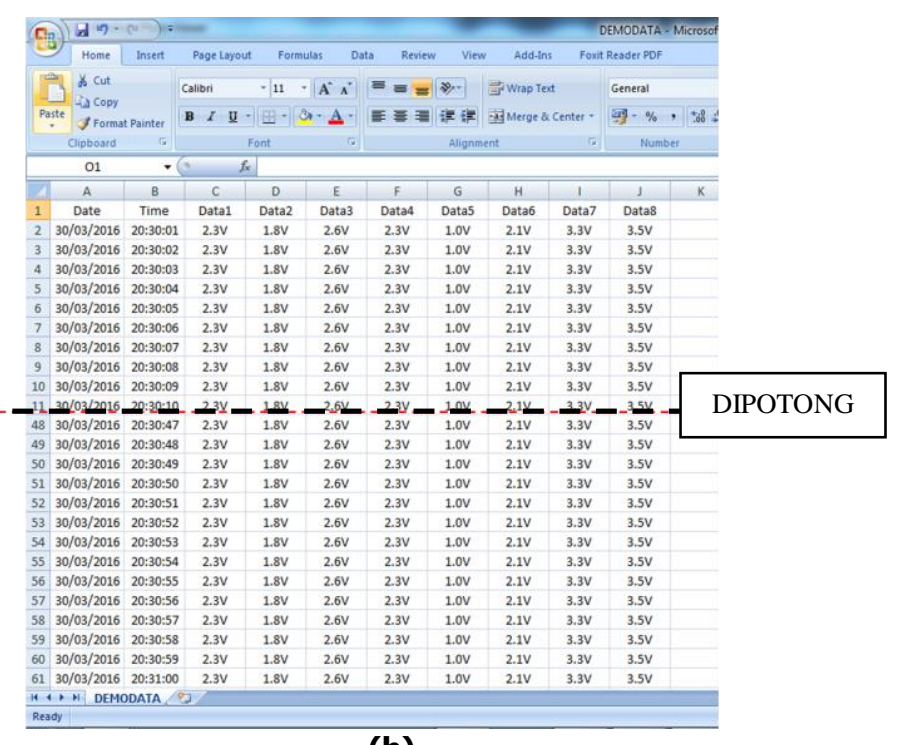

(b)

Gambar 31.(a) Data yang diterima pada software Teminal secara wireless;(b) Data pada isi file SD card yang dibaca dengan software Excel

Dari kedua data yang telah didapat dilakukan verifikasi data guna mengetahui apakah data yang dikirim telah sesuai dengan data yang direkam. Hasil dari verifikasi kedua data tersebut 
adalah tidak terjadi data yang hilang. Hal ini terbukti dari 61 data yang tersimpan dalam SD card semuanya dapat terbaca pula pada software Terminal yang menampung data yang dikirim secara wireless.

Selain verifikasi data, dilakukan pula pengecekan dengan software WinHex untuk melihat isi dari SD card. Gambar 32 menampilkan window dari software WinHex.

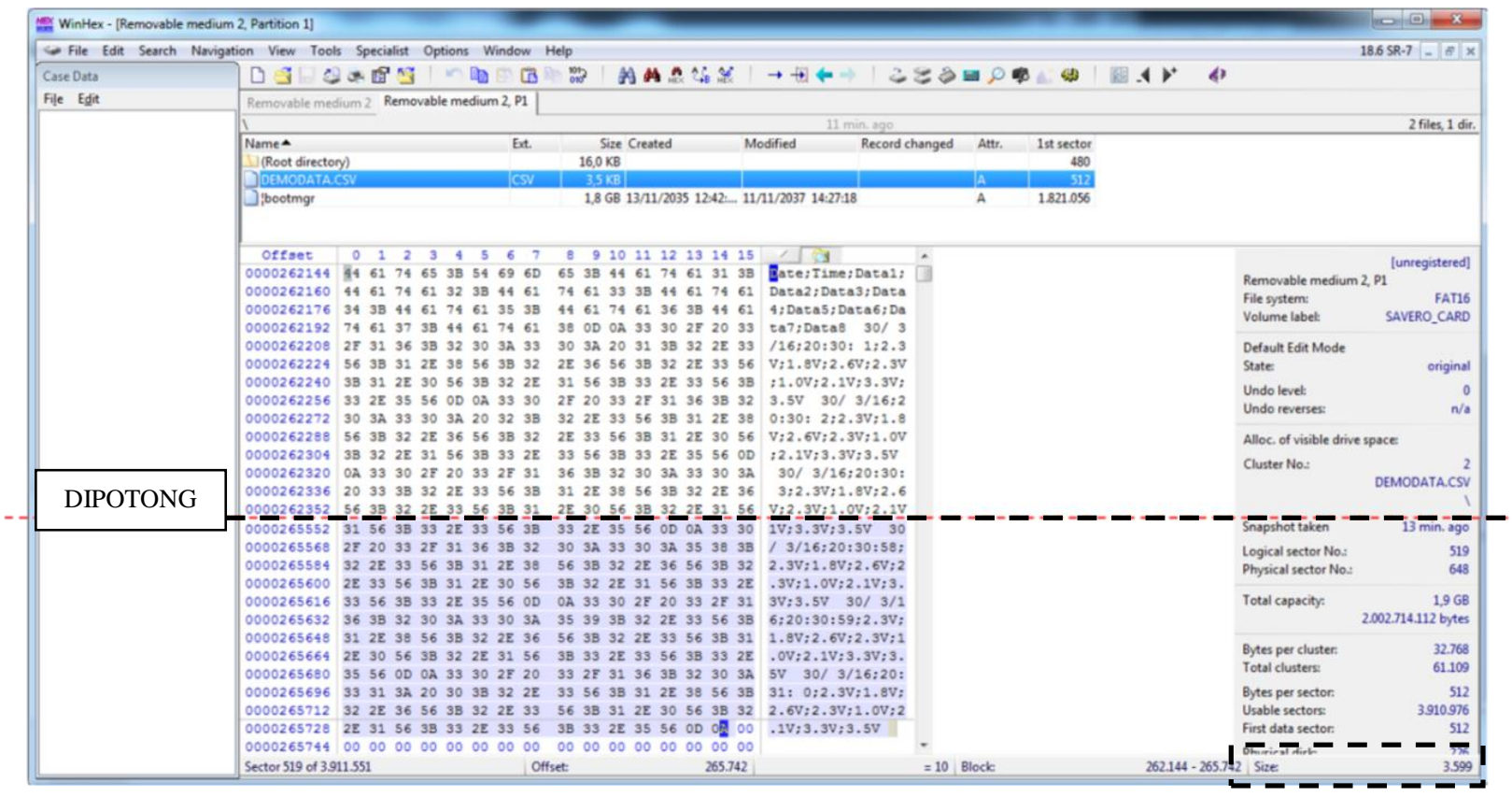

Gambar 32.Data yang dibaca pada software WinHex

Pada Gambar 32 dapat terlihat pada kotak (dengan garis putus-putus) mengenai ukuran dari file sebesar 3599 byte. Dari percobaan selama 1 menit dapat ditarik kesimpulan bahwa dalam perekaman data selama 1 menit dengan periodik pengambilan data setiap 1 detik menghasilkan data sebanyak 3599 byte atau 61 baris yang berisi 1 baris pertama mengenai header dan 60 baris selanjutnya mengenai data hasil perekaman.

Berdasarkan format paket data yang dibuat, dapat diperoleh persamaan untuk menentukan lama waktu perekaman data dan total byte data yang dapat direkam pada SD card selama waktu perekaman tersebut. Kedua persamaan ini memiliki hubungan satu dengan lainnya melalui jumlah data yang direkam.

Waktu perekaman data $=$ Jumlah data $x$ skala periodik

Total byte $=($ Jumlah data $x$ paket data $)+$ total byte baris pertama

Hasil perhitungan untuk total byte data yang direkam pada SD card melalui persamaaan 1 dan 2, selanjutnya akan dibandingkan dengan hasil pengujian yang didapat pada software WinHex.Berikut adalah contoh perhitungan untuk waktu perekaman 1 menit dengan skala periodik pengambilan data selama 1 detik.

- Perhitungan 1 menit dengan skala periodik 1 detik:

$$
\begin{aligned}
& \text { Jumlah data }=\frac{\text { Waktu perekaman data }}{\text { skala periodik }} \\
& \text { Jumlah data }=\frac{60}{1}=60 \mathrm{data}
\end{aligned}
$$


Setiap 1 paket data berisi 59 byte dan baris pertama berisi 59 byte, maka:

Total byte $=($ Uumlah data $\times$ paket data $)+$ total byte baris pertama

Total byte $=(60 \times 59)+59=3599$ byte

Sehingga untuk waktu perekaman 1 menit dengan skala periodik 1 detik menghasilkan 61 baris dengan 3599 byte dan telah sesuai dengan hasil yang didapat dari pengukuran.

Pengujian data logger dilakukan beberapa kali guna mengetahui apakah hasil perhitungan berdasarkan persamaan yang telah didapat sesuai dengan yang diukur. Pengujian ini menggunakan lama waktu yang beragam dengan skala periodik selama 1 detik dan 5 detik. Hasil pengujian dapat dilihat pada Tabel 6 dan 7.

Tabel 6.Perbandingan data yang direkam dengan perhitungan menggunakan periode 1 detik

\begin{tabular}{|c||c|c||c|c|}
\hline \multirow{2}{*}{ Waktu } & \multicolumn{2}{c||}{ Jumlah data } & \multicolumn{2}{c|}{ Total byte } \\
\cline { 2 - 4 } & Hasil pengukuran & Hasil perhitungan & Hasil pengukuran & Hasil perhitungan \\
\hline \hline 1 menit & 61 & 61 & 3599 byte & 3599 byte \\
\hline 3 menit & 181 & 181 & 10679 byte & 10679 byte \\
\hline 5 menit & 301 & 301 & 17759 byte & 17759 byte \\
\hline 10 menit & 601 & 601 & 35459 byte & 35459 byte \\
\hline 30 menit & 1801 & 1801 & 106259 byte & 106259 byte \\
\hline 1 jam & 3601 & 3601 & 212459 byte & 212459 byte \\
\hline 2 jam & 7201 & 7201 & 424859 byte & 424859 byte \\
\hline 3 jam & 10801 & 10801 & 637259 byte & 637259 byte \\
\hline
\end{tabular}

Tabel 7. Perbandingan data yang direkam dengan perhitungan menggunakan periode 5 detik

\begin{tabular}{|c||c|c||c|c|}
\hline \multirow{2}{*}{ Waktu } & \multicolumn{3}{c||}{ Jumlah data } & \multicolumn{2}{c|}{ Total byte } \\
\cline { 2 - 4 } & Hasil pengukuran & Hasil perhitungan & Hasil pengukuran & Hasil perhitungan \\
\hline \hline 1 menit & 13 & 13 & 767 byte & 767 byte \\
\hline 3 menit & 37 & 37 & 2183 byte & 2183 byte \\
\hline 5 menit & 61 & 61 & 3599 byte & 3599 byte \\
\hline 10 menit & 121 & 121 & 7139 byte & 7139 byte \\
\hline 30 menit & 361 & 361 & 21299 byte & 21299 byte \\
\hline 1 jam & 721 & 721 & 42539 byte & 42539 byte \\
\hline 2 jam & 1441 & 1441 & 85019 byte & 85019 byte \\
\hline 3 jam & 2161 & 2161 & 127499 byte & 127499 byte \\
\hline
\end{tabular}

\section{KESIMPULAN}

Berdasarkan perancangan, realisasi, dan hasil pengujian sistem yang telah dilakukan, maka penelitian ini dapat disimpulkan sebagai berikut:

1. Berdasarkan pengujian mengenai konfigurasi SPI, protokol komunikasi SPI antara mikrokontroler dengan SD card dapat menggunakan lebih dari satu Slave (dalam penelitian ini adalah SD card) dengan konfigurasi Independent Slave dengan cara memberikan logika low pada pin $\overline{\mathrm{SS}}$ dari Slave yang akan diajak berkomunikasi dan memberikan logika high pada pin $\overline{\mathrm{SS}}$ dari Slave yang lainnya seperti terlihat pada Gambar 16.

2. Berdasarkan pengujian mengenai proses read/write data pada SD card, proses ini telah berhasil dilakukan oleh mikrokontroler melalui 4 tahapan yang diawali inisialisasi SD 
card, pembacaan konfigurasi SD card, penulisan data pada SD card, dan pembacaan data SD card.

3. Berdasarkan Tabel 3 dapat disimpulkan bahwa crystal $4 \mathrm{MHz}-20 \mathrm{MHz}$ dapat digunakan untuk komunikasi SPI antara mikrokontroler dengan SD card dengan masing-masing nilai clock darisetiap crystal adalah crystal/2 - crystal/128.

4. Berdasarkan Tabel 6 dan 7 terlihat bahwa persamaan (1) dan (2) dapat digunakan untuk menghitung waktu perekaman data dan total byte, Sehingga persamaan (1) dan (2) dapat digunakan untuk melakukan perhitungan banyaknya data yang dapat direkam oleh SD card dengan kapasitas tertentu, seperti pada pengujian sistem data logger bahwa dengan skala periodik pengambilan data setiap 1 detik, SD card berkapasitas 2 GB mampu menampung data selama 1 tahun 27 hari 8 jam 11 menit 44 detik.

\section{DAFTAR RUJUKAN}

Badhiye, S.S., Chatur, P.N., Wakode, B.V. (2011). Data Logger System: A Survey. International Journal of Computer Technology and Electronics Engineering(IJCTEE): 2426.

Choudhury, S., Singh G.K., Mehra R.M. (2014). Design and Verification Serial Peripheral Interface (SPI) Protocol for Low Power Applications. International Journal of Innovative Research in Science, Engineering and Tecgnology: 16750-16758. ISSN: 2319-8753.

Dutta, K., P., Rai, P., Pandey, R. K.. (2014). Microcontroller Based Automatic Multichannel Temperature Monitoring System. International Journal of Advanced Research in Electrical, Electronics and Instrument Engineering. Vol 3, Issue 9: 11771-11777 ISSN : 2278-8875.

Hartono, R.. (2013). Perancangan Sistem Data Logger Temperature Baterai Berbasis Arduino Duemilanove. Proyek Akhir.

Kriti, J., et al. (2015). Design and Implementation of Microcontroller Based Speed Data Logger. GE-INTERNATIONAL JOURNAL OF ENGINEERING RESEARCH. VOL-3, ISSUE-5 IF-4.007: 139-145 ISSN: (2321-1717).

Nhivekar, G., S., Mudholker, R., R. (2011). Data Logger and Remote Monitoring System for Multiple Paramater Measurement Application. E-Journal of Science \& Technology (eJST). 55-62

SIMAK, V., HRBCEK, J., Juraj, Z. (2011). Modular Approach During On-Board Unit Development. Journal of Information, Control and Management Systems. Vol 9: 145-150

Setiono, A., et al. (2010). Pembuatan Dan Uji Coba Data Logger Berbasis Mikrokontroler Atmega32 Untuk Monitoring Pergeseran Tanah. Jurnal Fisika Himpunan Fisika Indonesia. Vol 10: 83-94. ISSN 0854-3046. 